Andrzej Michalik

Państwowa Wyższa Szkoła Zawodowa w Elblągu

\title{
ZWIĄZKI SPÓŁDZIELCZE JAKO NARZĘDZIE WSPIERANIA SPÓŁDZIELNI SOCJALNYCH
}

\section{WPRowadZEnIE}

Rozwój spółdzielni socjalnych poza wsparciem ze strony administracji publicznej i organizacji pozarządowych wymaga również zaangażowania ruchu spółdzielczego. Wskazać tutaj należy zwłaszcza na struktury spółdzielcze reprezentowane przez związki rewizyjne skupiające podmioty spółdzielcze podstawowego szczebla. Jako, że obecnie funkcjonujące jednostki tego typu nie posiadają już tej samej struktury organizacyjnej i zakresu kompetencji, jaki obowiązywał na przestrzeni ostatniego wieku, tym bardziej należy omówić ich funkcjonowanie na przełomie ostatnich osiemdziesięciu lat, aby móc wprowadzić stosowne zmiany w ustawie - prawo spółdzielcze, nad którą obecnie trwają prace. Pomoże to budować nowoczesne związki rewizyjne, które mogłyby skutecznie wspierać spółdzielnie socjalne w dobie wysokiego wykluczenia społecznego stanowiącego poważny problem wielu jednostek samorządu terytorialnego i ich mieszkańców. 
2. Ewolucja struktur spó£dZielczych w Polsce

1) Struktury organizacyjne ruchu spółdzielczego w czasie dwudziestolecia międzywojennego

Już na początku lat dwudziestych powstały pierwsze rozwiązania prawne pozwalające na integrację ruchu spółdzielczego. Zgodnie z art. 66 ustawy z dnia 20 października 1920 roku o spółdzielniach (Dz.U. $\mathrm{Nr}$ 111, poz. 733), spółdzielnie podstawowe mogły się łączyć w organizacje wyższego szczebla, zapewniając sobie w ten sposób możliwość własnego rozwoju i doskonalenia swojej struktury poprzez proces lustracji. Dawało im to szansę na dynamiczny rozwój w wielu segmentach ówczesnej gospodarki mimo niekorzystnej sytuacji ekonomicznej.

Wiele spółdzielni dobrowolnie przystępowało do tego typu organizacji zachęcanych korzyściami własnego rozwoju oraz demokratycznym sposobem zarządzania poprzez Zarząd czy Walne Zgromadzenie. Dzięki treści art. 67 ustawy o spółdzielniach możliwe stało się także powołanie do życia wyspecjalizowanych komórek, które wspierały spółdzielnie członkowskie w rozwijaniu ich potencjału gospodarczego. Podlegały one ścisłemu nadzorowi ze strony Krajowej Rady Spółdzielczej, która mogła cofnąć prawo do rewizji innych spółdzielni, gdy związek nie był w stanie realizować tego w należyty sposób.

Zmiany zachodzące w gospodarce światowej i dostosowanie spółdzielni do nowych realiów ekonomicznych wymusiło konieczność zmiany w samym sposobie nadzoru. Został dookreślony cel rewizji oraz zweryfikowano uprawnienia samych rewidentów. Wskazano także na obowiązki organów spółdzielni wobec osób dokonujących rewizji ze zwróceniem uwagi na konieczność dostarczania dokumentów potrzebnych do przeprowadzenia kontroli. Było to novum, które zostało następnie odzwierciedlone $\mathrm{w}$ innych ustawach regulujących kwestie nadzoru nad spółdzielniami. Sprawiło to, iż jednostki mogły rozwijać się znacznie sprawniej, co w okresie rodzącego się kryzysu lat trzydziestych miało nader istotne znaczenie ${ }^{1}$. Dodatkowo zweryfikowano także

1 H. Сıосн, Wpływ prawa spółdzielczego na rozwój spółdzielczości po 1989 roku, [w:] 90 lat prawa spółdzielczego, «Biuletyn Instytutu Stelczyka» 5/2010, s. 90. 
czas obowiązkowej rewizji, która zgodnie z art. 1 pkt. 25 ustawy z dnia 13 marca 1934 roku w sprawie zmiany ustawy o spółdzielniach (Dz.U. $\mathrm{Nr} 38$, poz. 342.) zaczęła być przeprowadzana raz na rok. Tym samym jednostki spółdzielcze mogły być sprawniej nadzorowane, a podejmowane działania lepiej dopasowane do konkurencji panującej na rynku. Pomimo pewnych pozytywów, te rozwiązania wpłynęły nie do końca właściwie na funkcjonowanie samego ruchu, zwłaszcza w zakresie istnienia związków spółdzielczych. Przede wszystkim ograniczono liczbę związków, które mogły prowadzić proces samej lustracji, co zdecydowanie negatywnie odbiło się na ich niezależności. Te organizacje, które otrzymały taką możliwość, stały się bardziej zależne od administracji publicznej, co doprowadziło w konsekwencji do utraty części ich autonomii, tak istotnej dla sektora spółdzielczości.

Na uwagę zasługuje także fakt konieczności zatwierdzania statutu związku rewizyjnego przez Ministra Skarbu. Zgodnie z art. 67 ustawy o spółdzielniach (tekst jedn. Dz.U. z 1934 r. Nr 55, poz. 495) każdy związek musiał przedłożyć taki dokument administracji publicznej, aby działać legalnie. Tym samym znacząco ograniczało to niezależność ruchu spółdzielczego, ponieważ wcześniej dokonywały tego same organizacje spółdzielcze, w tym zwłaszcza Rada Spółdzielcza. Wpływało to także na działalność wspomnianej organizacji, ponieważ zgodnie z art. 69 tejże ustawy każda zmiana statutu musiała również zostać przedstawiona do akceptacji Ministrowi Skarbu². Taki stan związany z uzależnieniem spółdzielczości od państwa trwał do rozpoczęcia drugiej wolny światowej.

2) Uzależnienie jednostek spółdzielczych od państwa w gospodarce centralnie planowanej

Zastąpienie struktur demokratycznych gospodarką planową doprowadziło również do zmian w strukturze organizacyjnej ruchu spółdzielczego. Przede wszystkim utworzono nowe struktury spółdzielcze, odbierając dotychczasowym posiadane przez nich statuty. Nowe

2 E. KoŁodziej, Spółdzielczość na terenie centralnych ziem polskich do roku 1939 [w:] Między idea, a polityką. Ruch spółdzielczy centralnych ziem polskich, red. A. DuSZYK, Radom 2007, s. 31. 
podmioty zyskały podstawę prawną, która wzmocniła ich uzależnienie do państwa. Na mocy art. 1 pkt. 2 dekretu z 24 sierpnia 1945 o zmianie ustawy z dnia 29 października 1920 roku o spółdzielniach (Dz.U. Nr 34, poz. 204) rząd zyskał możliwość nadania statutu łączenia spółdzielni nawet przy wyraźnym sprzeciwie jej członków. Tym samym dawny ruch spółdzielczy i forma tworzenia spółdzielni przestała istnieć na rzecz aktywności państwa w tej dziedzinie.

Odbudowywany ruch spółdzielczy został podporządkowany Związkowi Rewizyjnemu Spółdzielni R.P. jako najważniejszej organizacji spółdzielczej, prowadząc do osłabienia lub likwidacji dotychczasowych związków spółdzielczych. Całkowicie kontrolowana przez państwo organizacja prowadziła także działalność w zakresie odzyskiwania rejestrów spółdzielni, które zaginęły podczas wojny, wpływając tym samym na kształt ruchu spółdzielczego. W tamtym czasie na podstawie art. 1 ustawy z dnia 9 marca 1949 roku o zakładaniu rejestrów spółdzielni, których rejestry zaginęły lub uległy zniszczeniu (Dz.U. Nr 19, poz. 111), związek był jednym z kilku podmiotów, który mógł tworzyć nowe spółdzielnie. Taki proces był inicjowany przez organy spółdzielcze kontrolowane jednak przez administrację, nie zaś przez samych obywateli. $\mathrm{W}$ ten sposób całkowicie odcięto się od ideałów przedwojennych, co z czasem zostało jednak zmienione na gruncie prawa spółdzielczego ${ }^{3}$.

$\mathrm{Na}$ kanwie centralizacji instytucji spółdzielczych powołano do życia także Centralny Związek Spółdzielczy oraz centrale spółdzielni, do których przynależność miała charakter obligatoryjny. Na mocy art. 5 pkt. 2 oraz art. 29 pkt. 1 ustawy z dnia o Centralnym Związku Spółdzielczym i centralach spółdzielni (Dz.U. Nr 30, poz. 199) już w momencie powstania wspomniane spółdzielnie z automatu przynależały do takiej struktury zarówno na poziomie centrali, jak i regionu. W zdecydowany sposób naruszało to zasadę autonomii podejmowania decyzji przez spółdzielnie podstawowego szczebla, co wskazywało wyraźnie na upaństwowienie całego ruchu, podobnie jak utrzymana w przepisach

3 M. Rymsza, Druga fala ekonomii społecznej, a koncepcja aktywnej polityki społecznej, [w:] Kapitał społeczny, Ekonomia społeczna, red. T. KAźmierczaк, M. Rymsza, Warszawa 2007, s. 93. 
prawa konieczność wyrażenia zgody na każdą zmianę statutu spółdzielni podstawowego szczebla przez właściwą centralę związkową. Mimo tego, iż jest ona, jak w okresie przedwojennym, organizacją spółdzielczą, nie ma nic wspólnego z rzeczywistym ruchem spółdzielczym mającym charakter oddolnej aktywności samych członków.

Argumentem przemawiającym za uzależnieniem organizacji spółdzielczych od państwa było wprowadzenie statutów wzorcowych. Nadawane przez jednostki spółdzielcze wyższego rzędu miały usprawnić powstawanie nowych spółdzielni. W konsekwencji jednak doprowadziło to do sytuacji odwrotnej. Spółdzielnie podstawowego szczebla nie mogły swobodnie kształtować własnej organizacji, a w konsekwencji uzależniały się od poleceń z zewnątrz. Tym samym, to państwo kształtowało formę spółdzielczości, ograniczając do minimum aktywność obywateli w tym zakresie, co było właśnie celem art. 1 pkt. 5 ustawy z dnia 20 grudnia 1949 roku o zmianie ustawy z dnia 29 października 1929 roku o spółdzielniach oraz ustawy z dnia 21 maja 1948 roku o Centralnym Związku Spółdzielczym i centralach spółdzielni (Dz.U. Nr 65, poz. 524).

Zmieniło się to dopiero na początku lat sześćdziesiątych, kiedy to zmianie uległa definicja spółdzielni. Wskazano przede wszystkim na to, iż spółdzielnia zyskała charakter „organizacji dobrowolnej i samorządnej" i doprowadzono do aktywniejszej roli obywateli w tworzeniu tego typu organizacji. Pozwoliło to na powoływanie do życia nowych jednostek spółdzielczych bez tak głębokiej ingerencji administracji państwowej. Zgodnie z art. 160 ustawy z 17 lutego 1961 roku o spółdzielniach i ich związkach (Dz.U. Nr 12, poz. 61) w podobnym tonie dokonano również zmiany w zakresie tworzenia związków rewizyjnych. Mogły być one powoływane przez organizacje spółdzielcze podstawowego szczebla bez silnego zaangażowania czy inspiracji państwa. Zapewniało to częściowy powrót do ideałów autonomii ruchu spółdzielczego, chociaż otoczenie gospodarcze, ze względu na centralizację gospodarki, nadal było pewnym utrudnieniem dla jej działalności.

Czynnikiem ograniczającym niezależność był również nadal istniejący obowiązek przynależności związków rewizyjnych do central związkowych. Centralny Związek mógł realizować - poza działalnością instruktażową, inicjowaniem współpracy z władzami, tworzeniem 
projektów przepisów prawa dla spółdzielczości także działania w zakresie lustracji. Posiadał on w tym zakresie możliwość nadawania uprawnień lustratorom i prawa przekazania prowadzenia lustracji innym związkom. Tym samym na mocy art. 163 ustawy o spółdzielniach i ich związkach, kontrola w zakresie działalności spółdzielni pozostawała nadal w rękach państwa, mimo że związki rewizyjne mogły już powstawać bez większych przeszkód ${ }^{4}$.

Na korzyść związków spółdzielczych w porównaniu do poprzednich rozwiązań prawnych zapisanych we wcześniejszych ustawach zadziałało przyznanie im prawa do prowadzenia działalności gospodarczej. Mimo, iż ograniczone było ono do ułatwienia działalności spółdzielni członkowskich, był to znaczący postęp. Pozwalało im prowadzić ośrodki szkoleniowe, urządzenia socjalne i kulturalno-oświatowe celem zaspokajania potrzeb członków, realizując tym samym wsparcie dla społecznego celu istnienia spółdzielni, co było zgodne z celami art. 165 ustawy o spółdzielniach i ich związkach, podobnie jak prowadzenie tych podmiotów przez organy kolegialne i wspólny majątek ${ }^{5}$.

Same związki spółdzielcze nie doczekały się jednak ścisłej definicji prawnej. Mimo określenia celu, którym było wspieranie przynależących do nich spółdzielni, znacząco utrudniało im to funkcjonowanie i działalność w ruchu spółdzielczym. Ostatecznie ustawodawca zdecydował się na podanie pełniej definicji związku spółdzielczego dopiero na początku lat osiemdziesiątych. Zgodnie $\mathrm{z}$ art. 240 par. 1 ustawy $\mathrm{z}$ dnia 16 września 1982 roku - Prawo spółdzielcze (Dz.U. Nr 30, poz. 210) w brzmieniu z dnia jej uchwalenia za związek uznano samorządną organizację spółdzielczą. Tym samym zyskał on znaczącą autonomię, uniezależniając się od organizacji wyższego szczebla. Spółdzielnie wchodzące w skład takiego podmiotu zyskały szerszą możliwość kontroli poprzez swoich przedstawicieli w organach jednostki.

Poza przypisanymi wcześniej zadaniami związanymi z instruktarzem, lustracją spółdzielni, przygotowaniem i opiniowaniem projektów

\footnotetext{
4 J. Herbst, Kondycja ekonomii społecznej w Polsce, Warszawa 2006, s. 4.

5 Bliżej na ten temat pisze P. ZAKrzewsKI, Koncepcje stosunków majątkowych w prawie polskim, «Studia z Prawa Wyznaniowego» 6/2003.
} 
przepisów prawa w zakresie spółdzielczości oraz reprezentowaniem interesów spółdzielczości przed administracją i organizacjami międzynarodowymi, związki spółdzielcze zostały po raz pierwszy zobligowane w sposób bezpośredni do udzielania wsparcia powstającym spółdzielniom. Tym samym na mocy art. 240 par. 1 pkt. 6 ustawy z dnia 16 września 1982 roku - Prawo spółdzielcze (Dz.U. Nr 30, poz. 210) w brzmieniu z dnia jej uchwalenia, rozwój spółdzielni stał się bardziej dynamiczny niż wcześniej. Finansowa i organizacyjna pomoc była o tyle istotna, iż pozwoliła wzmacniać ruch spółdzielczy w okresie zmian gospodarczych, utrzymując stabilną liczbę miejsc pracy we wszystkich sektorach gospodarki narodowej.

3) Upadek organizacji spółdzielczych wyższego szczebla w okresie narodzin gospodarki rynkowej

Odzyskanie przez Polskę pełnej niezależności na początku lat dziewięćdziesiątych doprowadziło także do dynamicznych zmian zachodzących w samej gospodarce. Dotknęło to również ruch spółdzielczy oraz jego struktury. Pod wpływem działań administracji publicznej oraz w wyniku preferowania prywatnych form prowadzenia działalności gospodarczej spółdzielnie zostały postawione na drugi plan. Zlikwidowano organizacje spółdzielcze wyższego stopnia, obawiając się ich wpływu na rozwój gospodarczy jako struktur zakorzenionych w starym systemie.

W wyniku tych działań na mocy art. 1 ustawy z dnia 20 stycznia 1990 roku o zmianach w organizacji i działalności spółdzielczości (Dz.U. Nr 6, poz. 36) wszystkie związki spółdzielcze postawiono w stan likwidacji. Dotyczyło to zarówno centralnych związków spółdzielczych, jak i central działających w poszczególnych branżach. Majątek tych organizacji miał być przekazany innym podmiotom spółdzielczym zrzeszonym wcześniej w danym związku na podstawie właściwej umowy oraz innym spółdzielniom założonym przez pracowników likwidowanych zakładów celem kontynuowania działalności. Przekazanie mogło mieć charakter częściowej lub całkowitej odpłatności w zależności od stanu środków niezbędnych na pokrycie zobowiązań likwidowanego związku. Z racji na ważny interes społeczny ruchu, ustawodawca umożliwił również przekazanie majątku związku nieodpłatnie pod warunkiem przejęcia 
wszystkich zobowiązań na zasadach ogólnych ${ }^{6}$ Te części majątku, które nie miały służyć prowadzeniu działalności gospodarczej, powinny być przekazane na mocy art. 3 pkt. 6 ustawy o zmianach w organizacji i działalności spółdzielczości nowo tworzonym związkom rewizyjnym.

$\mathrm{O}$ ile rozdysponowanie majątku zostało zabezpieczone prawem pierwokupu na mocy art. 3 pkt. 12 ustawy o zmianach w organizacji i działalności spółdzielczości, o tyle sama struktura organizacyjna związków spółdzielczych nie doczekała się takiej aktywności ze strony ustawodawcy. Wszystkie ośrodki szkoleniowe, szkoły, urządzenia kulturowe i socjalne nieprzejęte przez organizacje spółdzielcze na mocy art. 5 ust. 2 tejże ustawy zostały przekazane odpowiednim ministerstwom, a w konsekwencji, w wyniku braku ich zainteresowania zlikwidowane. Tym samym, cała infrastruktura wspierająca rozwój spółdzielni na początku okresu transformacji została ograniczona do minimum. Bez takiej pomocy liczba spółdzielni istniejąca na początku lat dziewięćdziesiątych została drastycznie ograniczona we wszystkich sektorach gospodarki ${ }^{7}$.

Ruch spółdzielczy musiał być budowany od podstaw. O ile spółdzielnie podstawowego szczebla nadal istniały, próbując radzić sobie w nowych realiach gospodarczych, o tyle system wsparcia praktycznie nie istniał. Aby realizować zasadę samopomocy, spółdzielnie zaczęły ze sobą współpracować, budując związki rewizyjne dla odpowiednich sektorów gospodarki. Stało się to jednak możliwie dopiero po wyroku Trybunału Konstytucyjnego ${ }^{8}$, który uchylił niekonstytucyjny art. 19 ust. 1 tejże ustawy umożliwiający tworzenie takich podmiotów dopiero od 31 lipca 1991 roku. Tym samym przez blisko rok nie mogły być powoływane do życia żadne instytucje spółdzielcze drugiego stopnia, nawet te tworzone w oparciu o demokratyczne metody z inicjatywy samych spółdzielców. Znacząco ograniczało to pomoc w rozwoju spółdzielni podstawowego szczebla, a były one potrzebne zwłaszcza w nowych

6 Więcej na temat przejmowania nieodpłatnego majątku i ryzyka $\mathrm{z}$ tym związanego, także w orzecznictwie, można znaleźć w Wyroku SN z dnia 11 lutego 2010 roku, I CSK 385/09, «Legalis» nr 350635.

7 B. Brzozowski, Podstawy gospodarki spółdzielczej. Wybrane zagadnienia, Kraków 2008, s. 76.

8 Wyrok TK z dnia 4 styczna 1991 roku, K 6/90, «Legalis» nr 10086. 
sektorach spółdzielczych, między innymi tych o charakterze socjalnym. Niestety, bez wsparcia publicznego i zaangażowania władz był to proces niezwykle długotrwały. Jedyne wsparcie, na jakie mogły liczyć tego typu organizacje, to pomoc ze strony Krajowej Rady Spółdzielczej. Niestety, mogła ona dotyczyć tylko zaplecza doradczego, nie zaś finansowego, które było tak niezbędne zwłaszcza na początku tworzenia związku rewizyjnego danej branży9

3. INICJATYWY OBYWATELSKIE TWORZENIA ORGANIZACJI SPÓ£DZIELCZYCH DRUGIEGO STOPNIA W III RZECZYPOSPOLITEJ

1) Związek rewizyjny jako organizacja stymulująca rozwój sektora spółdzielni socjalnych

Związek rewizyjny to podmiot skupiający spółdzielnie podstawowego szczebla mający za zadanie wspierać ekonomiczny i gospodarczy rozwój swoich członków. Może on realizować to poprzez działalność instruktarzową, doradczą, szkoleniową, reprezentowanie interesów swoich członków na zewnątrz oraz inicjowanie współpracy z innymi podmiotami, w tym także $\mathrm{z}$ administracją państwową i samorządową ${ }^{10}$. Te działania mają istotne znaczenie zwłaszcza w przypadku nowego typu spółdzielni, które, wchodząc na rynek, muszą od podstaw budować swoją przewagę konkurencyjną na lokalnym rynku. Zwłaszcza ważna jest tutaj możliwość reprezentowania interesów spółdzielni socjalnej przed administracją w zakresie uzgadniania rozwiązań prawnych czy ochrony praw, które mogą przyspieszyć ich rozwój. Ze względu na stosunkowo, którą tradycję tych organizacji, takie skupianie się podmiotów ma nader istotne znaczenie ${ }^{11}$.

9 Więcej na temat związków rewizyjnych pisze P. Grzegorzewski, Spółdzielczość w polskiej gospodarce. Geneza oraz istota spółdzielczych form gospodarowania, «Pieniądze i Więź» 23/2006.

10 K. Kwapisz, Prawo spółdzielcze. Komentarz praktyczny, Warszawa 2011, s. 271.

11 K. PiAsecki, Kodeks postępowania cywilnego, II, Warszawa 2010, s. 56. 
Aby zapewnić taką możliwość integrowania się podmiotów podstawowego szczebla, ustawodawca określił minimalną liczbę spółdzielni, która jest niezbędna do założenia związku rewizyjnego. Zgodnie $\mathrm{z}$ art. 240 par. 1 ustawy z dnia 16 września 1982 roku - Prawo spółdzielcze ( tekst jedn. Dz.U. z 2003 r. Nr 188, poz. 1848 ze zm.) musi być to przynajmniej 10 spółdzielni danego typu. Jest to liczba niewielka, a korzyści wynikające $z$ udziału w tego typu organizacji są znaczące. Jest to istotne zwłaszcza w przypadku spółdzielni socjalnych, które poza tworzeniem miejsc pracy ograniczają również wykluczenie społeczne będące poważnym problemem wielu gmin.

Związek rewizyjny poza samymi celami istnienia i demokratycznym charakterem zarządzania ${ }^{12}$ odgrywa także istotną rolę $\mathrm{w}$ procesie prowadzenia przez spółdzielnie podstawowego szczebla działalności organizacyjnej. Przede wszystkim posiada możliwość zwoływania Walnego Zgromadzenia w przypadku bezczynności innych organów spółdzielni w tym zakresie. Dzięki temu istnieje możliwość zabezpieczenia interesów członków organizacji oraz wzmocnienia ich roli w nadzorze nad działalnością Zarządu. Ma to istotny związek zwłaszcza w sytuacji, gdy członkowie spółdzielni należą do kategorii osób wykluczonych i sami mogą nie poradzić sobie w podejmowaniu tak ważnych dla przyszłości spółdzielni decyzji1 ${ }^{13}$.

Dodatkowo przedstawiciele związku rewizyjnego na mocy art. 36 par. 8 ustawy z dnia 16 września 1982 roku - Prawo spółdzielcze (tekst jedn. Dz.U. z 2003 r. Nr 188, poz. 1848 ze zm.) mogą uczestniczyć z głosem doradczym w Walnym Zgromadzeniu. Pozwala to na kontynuowanie wsparcia członków spółdzielni również na etapie prac takiego organu i podejmowania decyzji, które sprzyjać będą rozwojowi spółdzielni socjalnej, nie zaś jej destabilizacji. Tym samym daje to poza wsparciem prawnym również to o charakterze mentalnym, dzięki czemu osoby defaworyzowane mogą czuć się pełnowartościowymi członkami bardziej

12 H. Сıоch, Prawo spółdzielcze, Warszawa 2011, s. 116.

13 Więcej na ten temat pisze C. PoDsIadLIK, Zebranie przedstawicieli i zebrania grup członkowskich spółdzielni-wybrane zagadnienia. Część 1, "Monitor Prawniczy» $1 / 2005$. 
pewni swoich racji ${ }^{14}$. Pobodną rolę, jak w przypadku spółdzielni, związki rewizyjne mogą pełnić również $\mathrm{w}$ innych sektorach gospodarki, tam, gdzie spółdzielnie mają istotną do spełnienia misję zwłaszcza w zakresie pomocy swoim członkom ${ }^{15}$.

W przypadku prowadzenia wsparcia dla spółdzielni socjalnych niezwykle istotne jest również dostęp do informacji. Tylko na tej podstawie możliwe jest bowiem podejmowanie właściwych działań, które mogą przynieść konkretne skutki dla organizacji. Związek rewizyjny może uzyskać dostęp do pełnych i wiarygodnych informacji na podstawie art. 41 par 4 ustawy z dnia 16 września 1982 roku - Prawo spółdzielcze ( tekst jedn. Dz.U. z 2003 r. Nr 188, poz. 1848 ze zm.). Dzięki temu rozwiązaniu istnieje konieczność przekazania do właściwego związku rewizyjnego protokołów z posiedzeń organów spółdzielni, w tym szczególnie z Walnego Zgromadzenia. Może stać się to podstawą nie tylko do prowadzenia dalszych możliwości odwoławczych, ale także do podjęcia poprzez związek decyzji o wystąpienie z możliwością postawienia spółdzielni w stan likwidacji w przypadku rażącego naruszenia przepisów ustawy lub postanowień statutu czy braku prowadzenia działalności gospodarczej, do której spółdzielnia została powołana co najmniej od roku. Zgodnie z art. 114 par. 2 ustawy z dnia 16 września 1982 roku Prawo spółdzielcze ( tekst jedn. Dz.U. z 2003 r. Nr 188, poz. 1848 ze zm.) spółdzielnia zabezpieczona jest w przypadku wszczęcia takiej procedury możliwościami odwoławczymi. Takie rozwiązanie nie tylko chroni interesy członków spółdzielni socjalnej, ale również daję szansę na podjęcie działań naprawczych celem zabezpieczania miejsc pracy dla osób wykluczonych, których szanse na znalezienie zatrudnienia na rynku pracy są znikome ${ }^{16}$. Wskazać również należy, iż w przypadku braku powiadomienia związku rewizyjnego o miejscu i czasie przeprowadzenia Walnego Zgromadzenia spółdzielni przynależącej do związku, może

\footnotetext{
14 C. Podsiadlik, op. cit.

15 Por. szerzej M. KLaus, Rejestracja podmiotów w Krajowym Rejestrze Sądowym-praktyczne wskazówki, «Monitor Prawniczy» 7/2007.

16 A. Helin, Ustawa o rachunkowości. Komentarz, Warszawa 2012, s. 650.
} 
istnieć podstawa do zaskarżenia uchwał podjętych na takim posiedzeniu. Może to doprowadzić do ich uchylenia na drodze sądowej ${ }^{17}$.

Niestety, związki rewizyjne nie mogą prowadzić działalności gospodarczej w przeciwieństwie do tych, które funkcjonowały do 1990 roku. Znacząco utrudnia to ich aktywność związaną chociażby z realizacją szkoleń czy doradztwa. Prowadzi bowiem do niemożności pozyskiwania dodatkowych środków na wspieranie ich członków. Odebranie tego przywileju nastąpiło na mocy art. 1 pkt. 130 ustawy z dnia 7 lipca 1994 roku o zmianie ustawy - Prawo spółdzielcze oraz o zmianie niektórych innych ustaw (Dz.U. Nr 90, poz. 419 ze zm.), co znacząco wpłynęło także na liczbę aktywnie działających związków rewizyjnych, które zaczęły korzystać jedynie ze środków własnych jako podstawy działalności.

Pewną próbą zadośćuczynienia związkom rewizyjnym w tym zakresie przez ustawodawcę było zastosowanie zwolnienie z podatków dochodów związków rewizyjnych przeznaczonych na działalność statutową na mocy art. 17 pkt. 39 ustawy z dnia 15 lutego 1992 o podatku dochodowym od osób prawnych (tekst jedn. Dz.U. z 2011 r. Nr 74, poz. 397 ze zm.). Tym samym, aby skorzystać z tego dobrodziejstwa, należy niezwykle precyzyjnie określić zapisy statutu jako podstawowego dokumentu regulujące kwestie funkcjonowania organizacji spółdzielczej drugiego stopnia. Wskazać tutaj zwłaszcza należy na dookreślenie celów statutowych takiego podmiotu, które muszą być możliwie jasno sprecyzowane, nie budząc wątpliwości, ani organów podatkowych, ani tym bardziej członków Zarządu związku rewizyjnego ${ }^{18}$.

Mimo ciągłych kampanii informacyjnych prowadzonych przez Krajową Radę Spółdzielczą, nadal pojawiają się pewne wątpliwości w tym zakresie. Wskazać można chociażby na to, czy wyremontowanie budynku służącego prowadzeniu zarówno działalności statutowej organizacji, jak

17 Por. Wyrok SA w Łodzi z dnia 22 października 2013 roku, I ACa 523/13, «Legalis» nr 717423.

18 Więcej na ten temat przy komentarzu do art. 17 pkt. 39 ustawy z dnia 15 lutego 1992 o podatku dochodowym od osób prawnych (tekst jedn. Dz.U. z 2011 r. Nr 74, poz. 397 ze zm.) można znaleźć w komentarzach do ustawy, m. in. W. DмосH, Podatek dochodowy od osób prawnych. Komentarz, Warszawa 2014 oraz A. OвоńsкA, A. WŁACŁAWCZYк, Podatek dochodowy od osób prawnych. Komentarz, Warszawa 2013. 
i wynajmowi pomieszczeń spółdzielniom rozpoczynającym działalność gospodarczą można uznać za w pełni zwolnione z podatku. Okazuje się, iż opodatkowaniu podlega ta część remontu, która służy wynajmowi pomieszczeń uznanych przez organy skarbowe za właściwe do prowadzenia działalności komercyjnej, nie zaś statutowej ${ }^{19}$, podobnie jak w przypadku przeznaczenia dochodów $\mathrm{z}$ badania sprawozdań finansowych na cele statutowe. Działalność ta została uznana za prowadzenie działalności gospodarczej pomimo zapisów w statucie, iż tego typu działalność ma za zadanie wspierać rozwój spółdzielni ${ }^{20}$. Zupełnie inaczej do tej kwestii odniesiono się w przypadku prowadzenia działalności związanej z badaniem sprawozdań finansowych przez związek rewizyjny banków, gdzie nie uznano tego za działalność gospodarczą. Wynika to natomiast $\mathrm{z}$ bezpośrednich i czytelnych zapisów statutu tego związku, który bezpośrednio wskazywał na prowadzenie analizy sprawozdań jako celu statutowego ${ }^{21}$.

Związki spółdzielcze nie są osamotnione w podobnych wątpliwościach interpretacyjnych w zakresie kwestii zwolnień środków przeznaczonych na cele statutowe. W trybie tym pojawiają się interpretacje administracji skarbowej także wobec kółek rolniczych czy izb gospodarczych skupiających przedsiębiorców. W przypadku kółek rolniczych wynajem pomieszczeń nie został uznany za działalność gospodarczą, a uzyskane $\mathrm{z}$ niej środki nie zostały obciążone podatkiem, w przeciwieństwie do wynajmu pomieszczeń przez związek rewizyjny, mimo identycznego celu działania i identycznej podstawy prawnej zwolnienia ${ }^{22}$. Wynika ona bezpośrednio z art. 17 pkt. 39 ustawy z dnia 15 lutego 1992 o podatku dochodowym od osób prawnych (tekst jedn. Dz.U. z 2011 r. Nr 74, poz. 397 ze zm.). Natomiast w przypadku izb gospodarczych przedsiębiorców

19 Bliżej na ten temat: Interpretacja Dyrektora Izby Skarbowej w Katowicach z dnia 27 września 2013 roku, BPBI/2/423-802/13/PC.

20 Bliżej: Interpretacja Naczelnika Drugiego Urzędu Skarbowego w Katowicach z dnia 11 maja 2005 roku, IIUS PBI/PM/423-14/05.

21 Więcej: Interpretacja Dyrektora Izby Skarbowej w Warszawie z dnia 16 kwietnia 2010 roku, IPPB5/423-91/10-4/AM.

22 Por. Interpretacja Dyrektora Izby Skarbowej w Łodzi z dnia 4 kwietnia 2013, IPTPB3/423-2/13-5/MF. 
wskazano, podobnie jak w przypadku związków rewizyjnych, iż istnieje zdecydowane rozdzielenie nieruchomości związanej z prowadzeniem działalności statutowej i tej o charakterze gospodarczym, podobnie jak miało to miejsce w przypadku związków rewizyjnych. Tym samym, zwolnieniu z podatku od osób prawnych mogły podlegać jedynie te działania, które związane są bezpośrednio z tą częścią nieruchomości, która dotyczy prowadzenia działalności gospodarczej ${ }^{23}$.

Wskazać należy, iż związki rewizyjne pełnią istotną rolę w zakresie wspierania spółdzielni, w tym także tych socjalnych. Dążyć należy do tego, aby ich udział w tworzeniu tego typu organizacji był możliwie jak największy, dzięki czemu również ich szanse na lokalnym rynku zdecydowanie wzrosną.

2) Ogólnopolski Związek Rewizyjny Spółdzielni Socjalnych jako reprezentant spółdzielni socjalnych w ruchu spółdzielczym

Spółdzielczość socjalna jest stosunkowo nowym elementem ruchu spółdzielczego. Jej rozwój możliwy jest nie tylko dzięki wsparciu samorządu i organizacji pozarządowych, ale także związków spółdzielczych. Wskazać tutaj można zwłaszcza na związki rewizyjne skupiające spółdzielnie socjalne. Tego typu podmiotem jest właśnie OZRSS, który integruje ruch spółdzielczy tego sektora. Jest to organizacja o charakterze obywatelskim, oddolnym, powstałym w wyniku aktywności samych członków spółdzielni socjalnych, zwiększająca reintegrację społeczną i zawodową swoich członków.

Przynależność do tego typu organizacji ma oczywiście w pełni dobrowolny charakter, co zapewnia jej członkom także szeroką autonomię. Decyduje o tym w stosownej uchwale Walne Zgromadzenie takiej spółdzielni socjalnej. Nie oznacza to bynajmniej, iż sam związek nie ma możliwości ochrony swoich interesów w przypadku naruszenia przez nich prawa lub działanie na jego szkodę. Zgodnie z par. 14 tj. Statutu OZRSS z dnia 8 listopada 2012 roku, może on podjąć decyzję o wykluczeniu takiego członka. Nie pozostaje on jednak bez możliwości

${ }^{23} \mathrm{~W}$ tej kwestii więcej informacji można znaleźć w Interpretacji Dyrektora Izby Skarbowej w Warszawie z dnia 5 grudnia 2013 roku, IPPB5/423-701/13-4/KS. 
odwoławczych, które umożliwiają mu odwołanie się do Rady związku na mocy par. 16 Statutu OZRSS. Podobna niezależność związana jest również z prowadzeniem samego związku. Dzięki rozdzieleniu kompetencji na kolegialne organy, Zarząd, Walne Zgromadzenie oraz Radę, istnieje możliwość prowadzenia pełnej transparentności działań, co jest niezwykle istotne zwłaszcza w przypadku związku skupiającego organizacje osób defawaworyzowanych ${ }^{24}$.

Uczestnictwo w związku pociąga za sobą szereg korzyści. Członkowie mogą przede wszystkim podnosić kompetencje swoich pracowników poprzez uczestniczenie ich we właściwych szkoleniach w zakresie prawa czy zarządzania. Tym samym, spółdzielnie socjalne mogą się od siebie wzajemnie uczyć dobrych praktyk, co pozwala im podnosić konkurencyjność i stawać się prawdziwymi przedsiębiorcami tworzącymi miejsca pracy dla osób wykluczonych. Prowadzi to do wspierania realizowanych przez nie ich własnych zapisów statutowych związanych z krzewieniem ideałów spółdzielczości socjalnej zgodnie z zapisem par. 6 Statutu OZRSS. Uzupełnia to niejako funkcjonujące w całym ruchu zasady spółdzielczości z Kongresu Spółdzielczości w Manchesterze ${ }^{25}$. Szkolenia mogą dotyczyć nie tylko szeregowych pracowników spółdzielni, ale także kadry menedżerskiej. Tym samym udział w związku rewizyjnym zapewnia pełne wyszkolenie pracowników sektora spółdzielczego.

Integrowanie się ruchu ma jeszcze jedno istotne znaczenie. Związek rewizyjny może na przykład reprezentować swoich członków przed organami chroniącymi interesy konsumentów. Dla spółdzielni z racji na ograniczanie kosztów lepiej jest zwrócić się o pomoc do przedstawicieli związku, którzy mogą na mocy art. 19 ust. 1 pkt. 2 ustawy z dnia 16 kwietnia 1993 roku o zwalczaniu nieuczciwej konkurencji (tekst jedn. Dz.U. z 2003 r. Nr 153, poz. 1503 ze zm.) podjąć działania umożliwiające wystąpienie w imieniu spółdzielni o odszkodowanie od konkurenta lub zaniechanie niekorzystnych działań. Taka aktywność jest możliwa

24 J. LAMPrecht, Informacja na temat Ogólnopolskiego Związku Rewizyjnego Spótdzielni Socjalnych, [w:] Nowa gospodarka społeczna w rozwoju regionalnym i lokalnym, red. E. LEś, M. OŁDAK, Warszawa 2008, s. 333.

25 Zobacz bliżej P. Zakrzewski, Zasady Międzynarodowego Związu Spółdzielczego, «Kwartalnik Prawa Prywatnego»1/2005. 
jedynie, gdy związek ma wpisane do statutu odpowiednie uprawnienia - tak jest również w przypadku OZRSS - tym samym, może on realizować podobne zadania.

Z korzyścią dla członków związku oraz innych spółdzielni istotne jest $z$ kolei prowadzenie procesu lustracji przez związek rewizyjny. Jest to proces obowiązkowy, któremu raz na trzy lata muszą się poddać zarówno spółdzielnie socjalne przynależące do związku, jak również te niebędące jego członkami w wyniku właściwej treści art. 91 ustawy z dnia 16 września 1982 roku - Prawo spółdzielcze (tekst jedn. Dz.U. z 2003 r. Nr 188, poz. 1848 ze zm.). Procedura ta jest korzystna zwłaszcza w przypadku spółdzielni socjalnej, ponieważ pozwala nie tylko znaleźć przyczyny nieprawidłowości, ale także podjąć działania naprawcze skutkujące utrzymaniem miejsc pracy dla osób wykluczonych. Związek rewizyjny może w tym przypadku prowadzić proces takiej lustracji, co jest korzystne zwłaszcza ze względu na znajomość branży, a tym samym zagrożeń czyhających na przedsiębiorcę. Dzięki temu może on skutecznie doradzać podjęcie kroków zaradczych także w czasie prowadzenia lustracji lub na etapie realizacji wniosków polustracyjnych ${ }^{26}$. Wydaje się tym samym, iż pomysł przeniesienia prowadzenia procedury lustracji postulowany przez część sił politycznych wydaje się być w tym zakresie chybiony, zwłaszcza gdy istnieją stosowne rozwiązania zabezpieczające doskonalenie umiejętności samych lustratorów ${ }^{27}$.

Pomimo licznych zalet wynikających z przynależności do związku, do tej pory niestety, liczba tych organizacji w OZRSS nie ulega znaczącej zmianie mimo nowopowstających spółdzielni socjalnych. Nie powstają także nowe związki rewizyjne. Wiele podmiotów nie przystępuje do organizacji spółdzielczych, w tym także do związków rewizyjnych,

26 Na ten temat bliżej pisze K. Pietrzy коwsкi, Zmiany w prawie spółdzielczym, «Monitor Prawniczy» 21/2005.

27 Więcej informacji na temat przyznawanie uprawnień lustracyjnych ich kontroli można znaleźć w Kodeksie Etyki Lustratora stanowiącym załącznik do Uchwały nr 10/2010 Zgromadzenia Ogólnego Krajowej Rady Spółdzielczej z dnia 1 lipca 2010 roku oraz w Instrukcji o organizacji lustracji spółdzielczych stanowiącej załącznik do Uchwały nr 9/2010 Zgromadzenia Ogólnego Krajowej Rady Spółdzielczej z dnia 1 lipca 2010 roku. 
w obawie przed kosztami ewentualnych składek. Ustawodawca dał jednak możliwość na mocy art. 16 ust. 1 pkt. 37 ustawy z dnia 15 lutego 1992 o podatku dochodowym od osób prawnych (tekst jedn. Dz.U. z 2011 r. Nr 74, poz. 397 ze zm.) uznania tych składek za koszt uzyskania przychodu. Pozwala to zmniejszyć obciążenie finansowe nie tylko spółdzielni, ale i typowych przedsiębiorców, którym związki rewizyjne lub izby gospodarcze mogą dać szansę na dynamiczny rozwój na lokalnym rynku, co jest zgodne także z opinią administracji skarbowej ${ }^{28}$. Wskazać jednak należy, iż w przypadku komercyjnych przedsiębiorców składki mogą być uznane za koszty uzyskania przychodu jedynie w przypadku przynależności takich podmiotów do określonej kategorii związków: izb gospodarczych, rzemieślniczych, samorządów zawodowych określonych przedsiębiorców, nie zaś stowarzyszeń skupiających również inne osoby fizyczne czy prawne ${ }^{29}$.

\section{Podsumowanie}

Z przeprowadzonej analizy wynika, iż związek rewizyjny odgrywa znaczącą rolę w budowaniu ruchu spółdzielczego oraz wzmacnianiu zdolności organizacyjnych swoich członków. Jest to szczególnie istotne w przypadku nowych typów spółdzielni, do których należy zaliczyć spółdzielnie socjalne. W obecnie trwających pracach nad nową ustawą - prawo spółdzielcze należy więc dążyć do upowszechnienia funkcjonowania tego typu organizacji na rynku, zwłaszcza w sektorach mających istotne znaczenia dla zwalczania wykluczenia społecznego oraz reintegracji społecznej i zawodowej jej członków. Należałoby w tym zakresie nałożyć obowiązek na Krajową Radę Spółdzielczą w zakresie propagowania idei związków rewizyjnych wśród nowopowstałych spółdzielni lub, idąc jeszcze dalej, jak jest to w części krajów Europy Zachodniej, wprowadzić obowiązek przynależności do tego typu podmiotów. Nie

28 Interpretacja Dyrektora Izby Skarbowej w Poznaniu z dnia 18 lutego 2013 roku, ILPB3/423-493/12-2/KS.

29 Wyrok WSA w Gdańsku z dnia 4 listopada 2010 roku, I SA/Gd 799/10, «Legalis» nr 326106. 
naruszałoby to znacząco zasady dobrowolności, a z pewnością doprowadziłoby do wzmocnienia gospodarczego samych spółdzielni oraz powstania większej liczby związków rewizyjnych stanowiących reprezentację spółdzielczości socjalnej wobec administracji samorządowej.

\section{CoOperative Unions as an Instrument for the Support of Social Cooperatives in Poland}

\section{Summary}

The article provides basic information on the evolution of cooperative unions in Poland. It shows the numerous advantages of membership of cooperative unions for individual cooperatives, which helps them on the road to economic and social success. This is particularly important for social cooperatives, whose aim is to act on behalf of their members' social and professional reintegration. The article describes the Polish union of social cooperatives, the country's only representative body for social cooperatives with the legal authority to act as a partner in discussions and negotiations with administrative bodies on new legislation relating to social cooperatives. The article is supplemented with a set of proposals concerning cooperative unions for the legislator's consideration in the draft of a new act on the cooperative movement.

Słowa kluczowe: związek rewizyjny, ruch spółdzielczości socjalnej, ewolucja związków spółdzielczych.

Keywords: cooperative union, social cooperative, the social cooperative movement, evolution of cooperative unions. 